\title{
Penentuan Harga Pokok Produksi Dalam Sistem Harga Pokok Pesanan Pada Pembuatan Sablon Karung Goni Di Percetakan Zaki Grafika Pekanbaru
}

\author{
EVA EFLINDA \\ Sekolah Tinggi Ilmu Ekonomi Riau \\ Jln. HR Subrantas KM 12 Panam, Pekanbaru, 28293 \\ E-mail : Eflinda01@gmail.com
}

\begin{abstract}
Determining the cost of production is very important to do considering that one of the benefits of information on the cost of production is to be able to determine the selling price to calculate the periodic profit or loss of the company. Percetakan Zaki Grafika is an SME company in the field of printing various products such as packaging / plastic / sacks, invitations, calendars, brochures, books, letterhead, envelopes, and so on. Data sources were obtained from primary data in the form of interviews with owners and direct observations, and secondary data sourced from literature and other literature supporting this research. In collecting the cost of production, the company uses a system of order prices. In practice Zaki Grafika Printing only does simple recording that is not in accordance with generally accepted accounting principles. Based on the results of research on one case, namely the order to make screen printing for gunny sacks, the cost of production or production costs consist of raw material costs, direct labor costs, and factory overhead costs. For factory overhead costs, appropriate rates need to be made, and in this case the researcher uses tariffs based on raw material costs. The researcher also designed an order fee card for Zaki Grafika Printing.
\end{abstract}

Keywords: cost of production, cost of goods ordered

Usaha kecil dan menengah (UKM) di berbagai negara, telah terbukti sangat tangguh sebagai salah satu penggerak perekonomian rakyat, termasuk di Indonesia. Hal ini karena kebanyakan para pengusaha kecil dan menengah berangkat dari industri keluarga atau rumahan. Dengan demikian konsumennya pun berasal dari kalangan menengah ke bawah.

Salah satu permasalahan yang muncul dalam suatu UKM adalah mengenai penentuan harga pokok produk yang diproduksinya. Penentuan harga pokok produksi ini sangat penting dilakukan mengingat salah satu manfaat dari informasi harga pokok produksi adalah dapat menentukan harga jual untuk menghitung laba atau rugi periodik perusahaan.

Harga pokok produksi dihitung berdasarkan pengumpulan dan penggolongan biaya, sesuai dengan produk yang diproduksi perusahaan. Dalam penentuan harga pokok produksi, informasi yang di butuhkan oleh perusahaan adalah informasi mengenai biaya bahan baku, biaya tenaga kerja, dan biaya overhead pabrik. Ketiga jenis biaya tersebut harus ditentukan secara cermat, baik dalam pencatatan maupun penggolongannya. Sehingga informasi pokok produksi yang dihasilkan dapat diandalkan, baik untuk penentuan harga jual produk maupun untuk perhitungan laba rugi periodik.

Penelitian ini bertujuan untuk mengetahui penentuan harga pokok produksi dalam sistem harga pokok pesanan yang dilakukan perusahaan pada pembuatan sablon karung goni di Percetakan Zaki Grafika Pekanbaru.

Baldric Siregar, Bambang Suripto, Dody Hapsoro, Eko Widodo Lp, Erlina Herowati, Lita Kusumasari, Nurofik (2013:13) menyatakan, bahwa istilah biaya berhubungan dengan kos (cost) dan biaya atau beban (expense). Kos adalah pengorbanan sumber ekonomi untuk memperoleh barang dan jasa yang diharapkan memberi manfaat sekarang atau masa yang akan datang. Saat barang 
dan jasa dimanfaatkan, kos akan menjadi biaya. Kos yang belum dimanfaatkan dikelompokkan sebagai aset. Biaya adalah kos barang dan jasa yang telah memberikan manfaat yang digunakan untuk memperoleh keuntungan.

V. Wiratna Sujarweni (2015:9) menyatakan, biaya mempunyai dua pengertian yaitu pengertian secara luas dan secara sempit. Biaya dalam arti luas adalah pengorbanan sumber ekonomi yang diukur dalam satuan uang dalam usahanya untuk mendapatkan sesuatu untuk mencapai tujuan tertentu baik sudah terjadi dan belum terjadi/baru direncanakan. Biaya dalam arti sempit adalah pengorbanan sumber ekonomi dalam satuan uang untuk memperoleh aktiva.

Dari definisi diatas dapat disimpulkan bahwa biaya adalah harga perolehan dari suatu pengorbanan sumber ekonomi untuk memperoleh barang atau jasa baik yang sudah terjadi maupun yang belum terjadi/baru direncanakan.

Baldric Siregar, Bambang Suripto, Dody Hapsoro, Eko Widodo Lo, Erlina Herowati, Lita Kusumasari, Nurofik (2013:28) penggolongan biaya berdasarkan fungsi pokok perusahaan manufaktur diklasifikasikan menjadi tiga, yaitu: (1)Biaya Produksi yang terdiri dari biaya bahan baku, biaya tenaga kerja, dan biaya overhead pabrik; (2) Biaya Pemasaran yaitu berbagai biaya yang terjadi untuk memasarkan produk dan jasa; (3) Biaya administrasi dan umum yaitu biaya yang terjadi dalam rangka mengarahkan, menjalankan, dan mengendalikan perusahaan untuk memproduksi barang jadi.

Harga pokok produksi pada dasarnya menunjukan harga pokok produk (barang dan jasa) yang diproduksikan dalam suatu periode akuntansi tertentu. Harga pokok produksi menurut Haryono dalam Helmina Batubara (2013), yaitu biaya untuk menghasilkan produk pada perusahaan manufaktur. Hansen dan Mowen (2004:48) menyatakan bahwa harga pokok produksi adalah mewakili jumlah biaya barang yang diselesaikan pada periode tertentu.

Informasi harga pokok produksi yang dihasilkan oleh perusahaan manufaktur memiliki banyak manfaat bagi manajemen. Mulyadi (2002:71) menyatakan bahwa manfaat informasi harga pokok produksi yaitu: menentukan harga jual produk, memantau realisasi biaya produksi, menghtung laba atau rugi periodik, menentukan harga pokok persediaan produk jadi dan produk dalam proses yang disajikan dalam neraca.

Harga pokok produksi atau biasa juga disebut biaya produksi. Kautsar Riza Salman dan Mochammad Farid (2016:33) menyatakan bahwa biaya produksi adalah biaya yang berkaitan dengan pembuatan barang dan penyediaan saja. Biaya produksi ini meliputi biaya bahan langsung, biaya tenaga kerja langsung, dan biaya overhead pabrik. Baldric Siregar, Bambang Suripto, Dody Hapsoro, Eko Widodo Lo, Erlina Herowati, Lita Kusumasari, Nurofik (2013:28) menyatakan bahwa bila biaya diklasifikasikan berdasarkan elemen biaya produksi maka biaya dibagi menjadi tiga yaitu (1) biaya bahan baku (raw material cost), (2) Biaya Tenaga Kerja Lasing (direct labour cost), (3) biaya overhead pabrik.

a. Biaya bahan baku adalah besarnya nialai bahan baku yang dimasukkan ke dalam proses Meproduksi untuk diubah menjadi barang jadi. Bahan baku langsung adalah bahan yang dapat ditelusuri ke barang atau jasa yang sedang diproduksi.

b. Biaya Tenaga Kerja Langsung adalah biaya tenaga kerja yang secara langsung berhubungan produksi barang jadi. Tenaga kerja kerja l;angsung adalah tenaga kerja yang yang dapat ditelusuri pada barang atau jasa yang sedang diproduksi.

c. Biaya Overhead Pabrik adalah biaya-biaya yang terjadi di pabrik 
selain biaya bahan baku langsung dan biaya tenaga kerja langsung. Overhead adalah semua biaya produksi selain dari bahan langsung dan tenaga kerja langsung.

Pengalokasian biaya ke unit produk dapat dilakukan dengan cara memasukkan unsur biaya produksi yang terdiri dari biaya bahan baku, biaya tenaga kerja langsung, dan biaya overhead pabrik yang dapat dibagi dalam biaya tetap dan biaya variabel. Baldric Siregar, Bambang Suripto, Dody Hapsoro, Eko Widodo Lo, Erlina Herowati, Lita Kusumasari, Nurofik (2013:36), menyatakan bahwa metode penentuan biaya penuh (full absorption costing) adalah penentuan biaya produk dengan cara menjumlahkan semua unsur biaya variabel maupun biaya tetap. Metode penentuan biaya variabel (variable costing) adalah penentuan biaya dengan cara memasukkan semua biaya variabel saja.

Dalam mengakumulasi biaya atau harga pokok, perusahaan dapat menerapkan dua metode yaitu metode penentuan harga pokok pesanan dan metode penentuan harga pokok proses. V. Wiratna Sujarweni (2015:71) menyatakan bahwa metode harga pokok pesanan adalah metode untuk memproduksi produk dan menentukan harga pokok produk perusahaan berdasarkan pesanan dari konsumen. Baldric Siregar, Bambang Suripto, Dody Hapsoro, Eko Widodo Lo, Erlina Herowati, Lita Kusumasari, Nurofik (2013:46), menyatakan bahwa dalam penentuan biaya pesanan, biaya produksi diakumulasikan per satuan pesanan dan dilakukan sejak pesanan mulai dikerjakan sampai pesanan selesai dikerjakan. Selanjutnya mengenai metode penentuan harga pokok proses $\mathrm{V}$. Wiratna Sujarweni (2015:87) mendefinisikan sebagai metode perhitungan harga pokok produk berdasarkan biaya yang diproduksi pada suatu periode produk. Pada metode ini barang dan jasa diproduksi secara masal dan identik. Baldric Siregar, Bambang Suripto, Dody Hapsoro, Eko Widodo Lo, Erlina Herowati, Lita Kusumasari, Nurofik
(2013:38) menyatakan bahwa biaya proses adalah penentuan biaya dengan cara mengumpulkan biaya berdasarkan proses produksi atau berdasarkan departemen. Metode ini tepat digunakan oleh perusahaan yang bekerja berdasarkan proses.

Baldric Siregar, Bambang Suripto, Dody Hapsoro, Eko Widodo Lo, Erlina Herowati, Lita Kusumasari, Nurofik (2013:46) menyatakan bahwa dalam penentuan harga pokok pesanan elemen biaya produksi yang terdiri dari biaya bahan baku, biaya tenaga kerja langsung, dan biaya overhead pabrik diakumulasikan untuk setiap pesanan. Ketiga biaya produksi dicatat di kartu biaya pesanan (job order csot sheet). Kartu biaya pesanan berguna untuk perhitungan total biaya per pesanan dan biaya per unit. Total biaya per pesanan adalah penjumlah semua biaya produk yang terjadi dan dibebankan ke pesanan terbeut.

Menurut Mulyadi (2003 : 196), bagi perusahaan yang produksinya berdasarkan pesanan, biaya overhead pabrik dibebankan kepada produk atas dasar tarif yang ditentukan dimuka. Sedangkan Sujarweni (2015:54) menyatakan Biaya overhead pabrik adalah semua biaya produksi selain biaya bahan baku langsung dan biaya tenaga kerja langsung atau semua biaya yang dikeluarkan oleh perusahaan terdiri dari biaya bahan baku tidak langsung, biaya tenaga kerja tidak langsung dan biayabiaya produksi lainnya yang tidak secara mudah dapat ditelusuri secara langsung pada proses produksi.

Menurut Sujarweni (2015:57) tarif biaya overhead pabrik adalah sejumlah uang yang akan dibayarkan perusahann untuk memenuhi biaya overhead pabrik. Dalam pembebanan biaya overhead pabrik dapat didasarkan pada tarif yang ditentukan dimuka.

Ada bermacam dasar yang dapat dipakai dalam memilih dasar pembebanan biaya overhead pabrik kepada produk. 
Diantaranya adalah: Satuan produk, biaya bahan baku, biaya tenaga kerja langsung, jam tenaga kerja langsung, dan jam mesin.

Ada berbagai macam dasar yang dapat dipakai untuk membebankan biaya overhead pabrik kepada produk, di antaranya adalah:

1) Satuan produk. Metode ini adalah yang paling sederhana dan yang langsung membebankan biaya overhead pabrik kepada produk. Beban biaya overhead pabrik untuk setiap produk dihitung dengan rumus sebagai berikut:

Tarif BOP

\begin{tabular}{ll} 
Taksiran BOP & \\
\hline $\begin{array}{l}\text { Taksiran Jumlah } \\
\text { yang dihasilkan }\end{array}$ &
\end{tabular}

2) Biaya bahan baku. Jika biaya overhead pabrik yang dominan bervariasi dengan nilai bahan baku (misalnya biaya asuransi bahan baku), maka dasar yang dipakai untuk membebankannya kepada produk adalah biaya bahan baku yang dipakai. Rumus perhitungan tarif biaya overhead pabrik adalah sebagai berikut:

\begin{tabular}{|c|c|}
\hline \multirow{3}{*}{ Tarif BOP } & Taksiran BOP \\
\hline & Taksiran $\quad$ Biaya \\
\hline & $\begin{array}{l}\text { Bahan Baku yang } \\
\text { Terpakai }\end{array}$ \\
\hline
\end{tabular}

3) Biaya tenaga kerja langsung. Jika sebagian besar elemen biaya overhead pabrik mempunyai hubungan yang erat dengan jumlah upah tenaga kerja langsung (misalnya pajak penghasilan atas upah karyawan yang menjadi tanggungan perusahaan), maka dasar yang dipakai untuk membebankan biaya overhead pabrik adalah biaya tenaga kerja langsung. Tarif biaya overhead pabrik dihitung dengan rumus sebagai berikut:

\begin{tabular}{|c|c|c|}
\hline & Taksiran & \\
\hline Tarif BOP & $\begin{array}{l}\text { Taksiran } \\
\text { Tenaga } \\
\text { Langsung }\end{array}$ & $\begin{array}{l}\text { Biaya } \\
\text { Kerja }\end{array}$ \\
\hline
\end{tabular}

4) Jam tenaga kerja langsung. Jika biaya overhead pabrik mempunyai hubungan erat dengan waktu untuk membuat produk, maka dasar yang dipakai untuk membebankan adalah jam tenaga kerja langsung. Tarif biaya overhead pabrik dihitung dengan rumus:

$\begin{array}{lll}\text { Tarif BOP } & \text { Taksiran BOP } & \text { 100\% } \\ & \begin{array}{l}\text { Taksiran Jam Kerja } \\ \text { Langsung }\end{array} & \end{array}$

5) Jam mesin. Apabila biaya overhead pabrik bervariasi dengan waktu penggunaan mesin (misalnya bahan bakar atau listrik yang dipakai untuk menjalankan mesin), maka dasar yang dipakai untuk membebankannya adalah jam mesin. Tarif biaya overhead pabrik dihitung sebagai berikut:

\begin{tabular}{lll} 
& \multicolumn{2}{l}{ Taksiran BOP } \\
\cline { 2 - 3 } Tarif BOP & $\begin{array}{l}\text { Taksiran } \\
\text { Mesin }\end{array}$ & Jam
\end{tabular}

\section{METODE}

Penelitian dilakukan pada Percetakan Zakki Grafika yang beralamat di jalan Punai No.34A Sukajadi Pekanbaru. Perusahaan Zaki Grafika ini bergerak dibidang pencetakan berbagai produk seperti kemasan/plastik/karung, undangan, kalender, brosur, buku, kop surat, amplop, dan lain sebagainya. Perusahaan ini dipimpin oleh pemiliknya langsung yaitu Bapak Mulyadi. Sampai saat ini pengelolaan usaha ini masih sederhana dan kekeluargaan. Sederhana secara manajemen,dimana pemilik terlibat langsung dalam proses produksi, pemasaran dan pemastian kualitas produk. Sedangkan tenaga kerja juga menggunakan kerabat dekat sebagai karyawan.

Waktu pelaksanaan penelitian dimulai dari Agustus sampai dengan September 2018. Penelitian ini dilaksanakan dengan persetujuan dari pemilik percetakan Zaki Grafika.

Sugiono (2016), menyatakan jenis data terbagi 2 yaitu:

1. Data kualitatif adalah data yang diuraikan dalam bentuk deksripsi/narasi. 
2. Data Kuantitatif adalah data yang diuraikan dalam bentuk angka.

Sugiono (2016), menyatakan sember data terbagi 2, yaitu:

1. Data primer adalah sumber data yang langsung memperikan data kepada pengumpul data.

2. Data sekunder adalah sumber data tidak langsung memberikan data kepada pengumpul data.

\section{Teknik Pengumpulan Data}

1. Metode Interview atau Wawancara. Pada penelitian ini penulis mendapatkan data atau informasi melalui teknik wawancara dengan pemilik Percetakan Zakki Grafika Sukajadi Pekanbaru.

2. Metode Observasi. Penulis mengamati kegiatan yang berhubungan dengan Biaya dan Penentuan Harga Pokok Produksi pada Percetakan Zakki Grafika Sukajadi Pekanbaru.

Untuk menganalisis data yang diperlukan maka penulis menggunakan metode studi kasus. Menurut Sugiono (2015:17) menyatakan, studi kasus adalah merupakan salah satu jenis penelitian kualitatif, dimana peneliti melakukan eksplorasi secara mendalam terhadap program, kejadian proses, aktivitas terhadap satu atau lebih orang. Suatu kasus terikat oleh waktu dan aktivitas dan peneliti melakukan pengumpulan data secara mendetail dengan menggunakan berbagai prosedur pengumpulan data dan waktu yang berkesinambunganyaitu menyajikan data yang diperoleh dari Percetakan Zakki Grafika Sukajadi Pekanbaru kemudian diberikan argumentasi yang kemudian akan digunakan sebagai dasar untuk menyajikan kesimpulan dan saran.

\section{HASIL}

Hasil penelitian yang dilakukan pada Percetakan Zaki Grafika terhadap penentuan harga pokok produknya, diketahui bahwa perusahaan belum melakukan perhitungan harga pokok produknya. Oleh karena itu penulis melakukan penelusuran terhadap biaya produksi yang dikeluarkan oleh Percetakan Zaki Grafika, untuk 1 kasus pesanan, yaitu pesanan sablon dari Bapak Suker untuk mencetak karung goni sebanyak 2.000 lembar dengan harga Rp 250/lembar, dengan ketentuan karung goni sudah tersedia. Pekerjaan sablon dikerjakan selama 5 jam oleh 2 (dua) orang pekerja ditambah dengan persiapan (membuat film, menyiapkan alat dan tempat) 2 jam dengan upah pekerja Rp. 75.000,- per orang. Bahan Baku sablon terdiri dari film sablon senilai Rp. 15.000,-,1 Kaleng (Satu Warna) terpakai $80 \%$ senilai $\mathrm{Rp}$ 65.000, dan Pengencer Tinta 1 liter senilai Rp 10.000,-

\section{PEMBAHASAN}

Dalam penentuan harga pokok produk, perlu diketahui jumlah masingmasing biaya produksi yang terdiri biaya bahan baku, biaya tenaga kerja langsung, dan biaya overhead pabrik. Biaya bahan baku dan biaya tenaga kerja langsung sudah dapat dipahami, namun untuk jumlah biaya overhead pabrik perlu dibuatkan tarif terlebih dahulu. Oleh karena itu penulis menghitung tarif menggunakan dasar biaya bahan baku. Tarif ini dipilih karena biaya overhead pabrik yang dominan bervariasi dengan nilai bahan baku. Rumus perhitungan tarif biaya overhead pabrik adalah sebagai berikut:

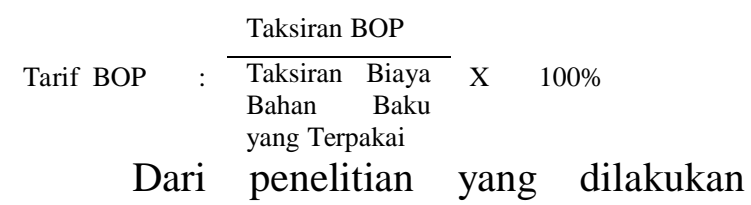
diketahui bahwa taksiran BOP dan taksiran biaya bahan baku per bulan dapat dihitung sebagai berikut: 
Tabel 1: Taksiran BOP

\begin{tabular}{|c|c|c|c|c|c|}
\hline No & Uraian & $\begin{array}{l}\text { Harga } \\
\text { Beli }\end{array}$ & $\begin{array}{l}\text { U. } \\
\text { E }\end{array}$ & $\begin{array}{l}\text { Penyusuta } \\
\text { n }\end{array}$ & Per Bulan \\
\hline \multirow[t]{8}{*}{1} & Peralatan & & & & \\
\hline & a. Screen & 150.000 & 2 & 75.000 & 6.250 \\
\hline & b. Rakel & 85.000 & 2 & 42.500 & 3.542 \\
\hline & c. Frame & 30.000 & 2 & 15.000 & 1.250 \\
\hline & $\begin{array}{ll}\text { d. } & \text { Alat } \\
\text { Pemotong } & \end{array}$ & 100.000 & 2 & 50.000 & 4.167 \\
\hline & $\begin{array}{ll}\text { e. } & \text { Papan } \\
\text { Triplek } & \\
\end{array}$ & 60.000 & 2 & 30.000 & 2.500 \\
\hline & f. Hair Driyer & 225.000 & 2 & 112.500 & 9.375 \\
\hline & g. Kipas Angin & 250.000 & 2 & 125.000 & 10.417 \\
\hline 2 & Sewa Tempat & & & 6.000 .000 & 500.000 \\
\hline \multirow[t]{2}{*}{3} & Biaya Listrik & & & & 240.000 \\
\hline & \multicolumn{4}{|c|}{ Taksiran BOP Per bulan } & 777.500 \\
\hline $\begin{array}{l}\text { Tal } \\
\text { ord }\end{array}$ & $\begin{array}{lll}\text { iiran } & \text { BOP } & P \\
r / b l n) & & \end{array}$ & Pesanan & (20 & 20 & 38.875 \\
\hline
\end{tabular}

Tabel 2: Taksiran Biaya Bahan Baku yang terpakai

\begin{tabular}{|c|l|l|l|l|}
\hline No. & Uraian & $\begin{array}{l}\text { Harga } \\
\text { Beli }\end{array}$ & Unit & $\begin{array}{l}\text { Biaya Bahan Baku } \\
\text { Per Bulan }\end{array}$ \\
\hline 1 & Film & 15.000 & 20 & \multicolumn{2}{|c|}{300.000} \\
\hline 2 & Tinta & 65.000 & 20 & 1.040 .000 \\
\hline 3 & $\begin{array}{l}\text { Pengencer } \\
\text { Tinta }\end{array}$ & 10.000 & 20 & 40.000 \\
\hline & \begin{tabular}{l} 
Total Bahan Baku Per Bulan \\
\hline
\end{tabular} & $\begin{array}{l}\text { Taksiran Biaya Bahan Baku } \\
\text { Per Pesanan }\end{array}$ & \multicolumn{2}{|c|}{$\mathbf{6 9 . 0 0 0}$} \\
\hline
\end{tabular}

Tarif BOP $=\frac{38.875}{69.000} \times 100 \%$

$$
=56,34 \%
$$

Berdasarkan kasus diatas, maka dapat disusun Harga Pokok Produksi (HPP) untuk pesanan bapak Suker pada Percetakan Zakki Grafika Sukajadi Pekanbaru seperti dalam tabel 3 berikut ini.

Tabel 3: Harga Pokok Produksi (HPP) Percetakan Zakki Grafika Atas Pesanan Sablon 2.000 lembar karung goni

\begin{tabular}{|c|c|c|}
\hline No & Keterangan & Total \\
\hline & Bahan Baku (A) & \\
\hline 1 & Film Sablon & $\mathrm{Rp} \quad 15.000$ \\
\hline 2 & Tinta Sablon & $\mathrm{Rp} \quad 65.000$ \\
\hline 3 & Pengencer Tinta & $\mathrm{Rp} \quad 10.000$ \\
\hline
\end{tabular}

\begin{tabular}{|c|c|c|}
\hline & Sub Total Bahan Baku & Rp 90.000 \\
\hline & Tenaga Kerja (B) & \\
\hline \multirow[t]{4}{*}{4} & $\begin{array}{l}\text { Tenaga Sablon } 2 \text { orang @ } \\
\text { Rp 75.000 }\end{array}$ & \\
\hline & Sub Total Biaya Tenaga Kerja & $\underset{150.000}{R p}$ \\
\hline & $\begin{array}{l}\text { Biaya } \quad \text { Overhead } \\
(56,34 \% \times \text { 90.000) }\end{array}$ & $\begin{array}{l}\mathbf{R p} \\
\mathbf{5 0 . 7 0 6}\end{array}$ \\
\hline & $\begin{array}{l}\text { HARGA POKOK } \\
\text { PRODUKSI }(\mathrm{A}+\mathrm{B}+\mathrm{C})\end{array}$ & $\underset{290.706}{R p}$ \\
\hline
\end{tabular}

Selanjutnya peneliti merancang Kartu Biaya Pesanan pada Pesanan (Order cetakan) sablon pada karung goni sebanyak 2.000 lembar yang sesuai dengan Metode Harga Pokok Produksi (HPP) pesanan yang ada.

\section{Tabel 4 : Kartu Biaya Pesanan}

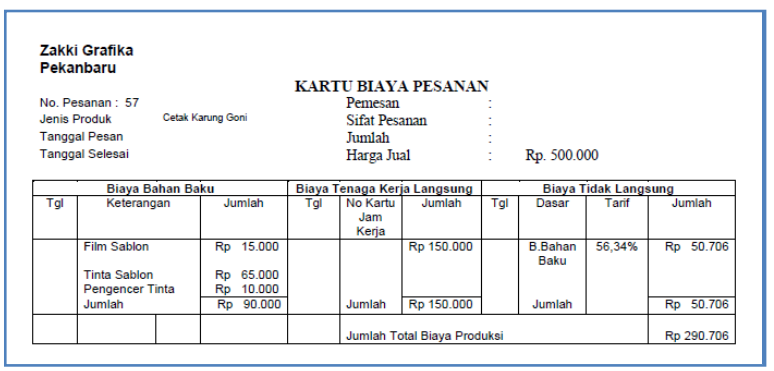

\section{SIMPULAN}

Penelitian ini dilakukan untuk mengetahui penentuan harga pokok produksi dalam sistem harga pokok pesanan yang dilakukan perusahaan dalam pembuatan sablon karung goni pada percetakan Zaki Grafika Pekanbaru. Dalam prakteknya perusahaan belum melakukan perhitungan harga pokok produk yang dihasilkannya sesuai dengan prinsip pencatatan dalam akuntansi. Harga pokok produksi atau biaya produksi dalam pembuatan sablon karung goni adalah biaya bahan baku, berupa film sablon, tinta sablon, dan pengencer, biaya tenaga kerja langsung, dan biaya overhead pabrik. Biaya bahan baku dalam pembuatan pesanan ini berjumlah Rp 90.000,-, biaya tenaga kerja berjumlah Rp 150.000,- dan biaya overhead pabrik sebesar Rp 50.706,- berdasarkan tarif 56,34\% dari biaya bahan baku yang digunakan, sehingga total harga pokok produksi dalam pembuatan pesanan sablon karung goni adalah sebesar 290,706,- 


\section{DAFTAR RUJUKAN}

Batubara, Helmina, Penentuan Harga Pokok Produksi Berdasarkan Metode Full Costing pada Pembuatan Etalase Kaca dan Alumunium di UD. Istana Alumunium Manado, 2013, Jurnal EMBA

Efferin, Sujoko \& Stevanus Hadi Darmaji, Yuliawati Tan, Metode Penelitian Akuntansi Mengungkap Fonomena dengan pendekatan Kuantitatif dan Kualitatif, 2008, Graha Ilmu, Yogyakarta.

Mulyadi, Activity-Based Cost System, 2003, Penerbit UPP AMP YKPN, Yogyakarta.

Salman, Kautsar Riza, SE. MSA. Ak. BKP. SAS. CA. \& Drs. Ec. Mochammad Farid, M.M., Akuntansi Manajemen Alat Pengukuran dan Pengambilan Keputusan Manajerial, 2016, Penerbit Indeks, Jakarta.

Samryn. L.M. SE, Ak, MM, 2012, Akuntansi Manajemen Informasi Biaya untuk Mengendalikan Aktivitas Operasi Dan Invesatasi, Kencana, Jakarta

Siregar, Baldric \& Bambang Suripto, Dody Hapsoro, Eko Widodo Lo, Erlina Herowati, Lita Kusumasari, Nurofik, 2013, Akuntansi Biaya, Salemba Empat, Jakarta.

Sugiyono. Prof., DR, 2010. StatistikaUuntuk Penelitian,Alfabeta, Bandung.

Sujarweni, V. Wiratna, 2015,Akuntansi Biaya Teori dan Penerapannya,Pustaka Baru Press, Yogyakarta. 